\title{
Thinking India in South Africa: Gandhi's Conundrum
}

Claude Markovits

\section{CpenEdition}

Journals

\section{Electronic version}

URL: http://journals.openedition.org/samaj/3762

DOI: $10.4000 /$ samaj.3762

ISSN: $1960-6060$

\section{Publisher}

Association pour la recherche sur l'Asie du Sud (ARAS)

Electronic reference

Claude Markovits, «Thinking India in South Africa: Gandhi's Conundrum », South Asia Multidisciplinary Academic Journal [Online], 10 | 2014, Online since 25 December 2014, connection on 01 May 2019. URL : http://journals.openedition.org/samaj/3762 ; DOI : 10.4000/samaj.3762

This text was automatically generated on 1 May 2019.

\section{(c) $($ ) $(9)$}

This work is licensed under a Creative Commons Attribution-NonCommercial-NoDerivatives 4.0 International License. 


\title{
Thinking India in South Africa: Gandhi's Conundrum
}

\author{
Claude Markovits
}

The term 'South Asia' was not in use before the 1950s, and did not therefore belong to Gandhi's lexicon. In analysing how Gandhi (1869-1948), in South Africa, between 1893 and 1914, 'thought India', we may however be able to approach indirectly some of the problems raised by the political/spatial conceptualization of the region that we now call 'South Asia'. Gandhi himself was certainly not interested in the question of naming that space, which for him, like for most of his contemporaries, was simply and unproblematically India, or Bharat. But in his own political practice, the question of spatiality occupied an important if somewhat unrecognized place, inasmuch as he started his public career in South Africa and relocated to India for good only at the age of 46 after having spent most of twenty years in Durban and Johannesburg. This is bound to raise interesting questions regarding Gandhi's perception of India and Indianness. We might note in passing that his twenty-year stay in South Africa remains a relatively neglected episode in most accounts of his life ${ }^{1}$ and in the vast literature generated around his thought and political practice. There is, however, a growing body of texts coming out of South Africa that has tended to offer a view that differs from the dominant Indian view, less hagiographical in nature, and more attuned to the local context. ${ }^{2}$ I shall make use of this literature up to a point, but shall try to give precedence to Gandhi's own writings. The latter fall into two distinct categories, on the one hand the texts he produced while in South Africa, mostly letters, newspaper articles, particularly those in his own Indian Opinion, and the occasional pamphlet, on the other hand the two narratives he penned in India in the 1920s, while in jail, of his South African experience, firstly the some two hundred pages devoted to it in the well-known Autobiography (representing approximately half the book), ${ }^{3}$ but also the more focused and detailed narrative entitled Satyagraha in South Africa written in 1924 in Gujarati and published in English in $1928 .{ }^{4}$ My focus here is not what these texts tell us about Gandhi, but the light they throw on perceptions of India from a location in the diaspora. I am not going to offer a narrative of Gandhi's South African years, but I shall be attentive to the gradual evolution of his ideas 
over the twenty-year-period that extends from his arrival in Durban from India in 1893 to his departure from Durban to England in 1914 on his way to India.

When Gandhi landed in Durban in 1893, British Indians had been immigrating to South Africa for more than thirty years. Before that, during the period of Dutch rule (1652-1795), Indian slaves had been brought to the Cape in significant numbers, but by the mid- $19^{\text {th }}$ century they had melted into the 'coloured' population of that colony. A new wave of migration had started when the first batch of indentured labourers were sent from British India to Natal in 1860 to work in the sugarcane plantations as an alternative to African labour. By the early 1890s, there were three distinct groups of Indians in the two British colonies of Natal and the Cape (the latter, I shall largely ignore, since they were few in number, and Gandhi never became very much involved with their problems) and in the Boer Republic of Transvaal (the so-called South African Republic). Firstly the indentured labourers, some 16,000 , who were still arriving every year from Calcutta and Madras to work in the sugarcane plantations with five-year contracts, at the expiration of which they could either re-enlist or seek return to India. The indenture system has sometimes been defined as 'a new system of slavery', ${ }^{5}$ and, although this is certainly an exaggeration, there remains the fact that indentured labourers, dismissively called 'coolies' by their employers and the authorities, worked in harsh conditions for little pay, were often subjected to physical violence, and had no rights as workers or citizens. The majority of these labourers in Natal (contrary to the situation in most other sugarproducing colonies of the British Empire, such as Guyana, Trinidad or Fiji) were Tamilians and Telingas who had come from Madras, but there was also a significant group of North Indians, Hindus as well as Muslims, who had come from the Bhojpur area (Eastern United Provinces and Western Bihar) through Calcutta. The second group of Indians, the most numerous (some 30,000) consisted of ex-indentured labourers who, at the expiration of their contract, had chosen to stay in Natal to cultivate their own plots of land or to work as domestic servants or in other menial occupations. In spite of being 'free', they were still considered to be 'coolies' and did not enjoy any political rights. That group also included a growing number of locally-born Indians, the children of indentured labourers, some of whom had received an English education in missionary schools. Of the latter, some had converted to Christianity, and they constituted an embryo of middle class. The third group consisted of 'free' or 'passenger' Indians who had come at their own expense, from the 1870s onwards, either from neighbouring Mauritius or from India. It was a small (some 5,000-strong in Natal, and less than 4,000-strong in Transvaal) but fairly diversified group in which the dominant element consisted of Gujarati Muslim traders, mostly Memons from Kathiawar, who were Sunnis, but also Bohras from Surat, who were Shi'a Ismailis. In Durban, they were generally known as 'Arabs'. These traders had brought with them from India clerks, who were often Hindus (as well as a few Parsis), and servants. The Gujaratis were general traders who catered to an African as well as to an Indian clientele, which brought them into competition with small European traders, either Britons or Eastern European Jews, a competition that was a major source of resentment towards the Indians on the part of the local whites. Some of these Gujaratis were very successful in business, and, having amassed wealth, had acquired voting rights (which were based on property and income qualifications). They constituted an elite, whose status was however precarious, and they feared the consequences of the grant of self-government to the Natal colony, which gave increased power to white settlers who were particularly hostile to them. There was also a small group of traders from Sindh, 
known as Sindworkies, who were specialized in the sale of curios and silk to Europeans. A distinct group consisted of small itinerant traders, hawkers, of various origins, who were active mostly in the Transvaal (some 2,000). I draw this detailed picture in order to stress the extreme heterogeneity of the Indian community that was to provide Gandhi with the opportunity to start his public career. The Indians of South Africa were a fairly representative sample of India's population, with Hindus and Muslims as well as North Indians and South Indians more or less evenly balanced, but with the added twist that the richest and most influential of them were Muslims, a situation that was of course different from the one that prevailed in India.

3 As is well known, Gandhi's original point of entry into this universe was through the Muslim Memon merchant network from his native town of Porbandar. Hired as a lawyer to assist in a court case pitting against each other two prominent Memon traders, he managed however to enlarge at an early stage his acquaintance to encompass other groups of Indians. He acquired from the early days of his stay, through personal experience, a keen feeling of the kind of discriminations the Indians were subjected to on the part of the white settlers, who were the dominant element in the newly selfgoverning colony of Natal, as well as in neighbouring Boer-ruled Transvaal. Some episodes are well known, like the night he spent in Pietermaritzburg railway station on his way to Pretoria after having been expelled from the first-class compartment of a train. ${ }^{6}$ What deserves notice is the extreme sensitivity shown by Gandhi, from the time of his arrival in South Africa, towards any slight directed at Indians, in clear contrast to the attitude of his merchant friends who, as they put it themselves, did not mind pocketing insults if they could pocket cash. ${ }^{7}$ Such sensitivity was closely linked to the high idea he then entertained of the value of the British imperial connection for India. He strongly objected to the fact that Indians, who were British subjects, could be treated so callously in a British colony, although their treatment in Natal was not really very different from the one they received in India at the hands of British civilians, which Gandhi had experimented at first hand. But the reason for that extra sensitivity was that, in Gandhi's view, when they were outside India, Indians, including the humblest of coolies, represented the country, so that any slight directed at them was actually an insult to India. In the same way, as they represented India, they had to be exemplary, for instance in matters of sanitation and hygiene, in which they were singularly lackadaisical (and we meet here with one of Gandhi's recurrent obsessions throughout his lifetime). Apart from Gandhi's own views, ${ }^{8}$ this question of sanitation was important, because it was often the pretext used by local colonial authorities to confine the Indians to certain locations, which tended to become real ghettoes.

The view held by Gandhi of the place of Indians in South Africa was ambivalent: inasmuch as both India and Natal were under British rule, moving from one to another was not like crossing a border, but at the same time Natal was an 'abroad' in which Indians were bound to observe high standards of behaviour so as not to cast aspersions on the prestige of the motherland. We can see that India for Gandhi was a country of the mind, or rather of the spirit, as much or even more than a physical space. Where there were Indians, there was India. Actually Natal or South Africa were rarely invoked by Gandhi as physical spaces endowed with specific qualities, although in the Introduction to Satyagraha in South Africa, he briefly enthused about the beauty of the land, be it through quotations rather than in his own words. ${ }^{9}$ In the same text, after having praised the grapes of the Cape (for which, as a teetotaller he had however no use), he marvelled at the fact that Indians had 
acclimatized the mango in South Africa and that the local mangoes compared in quality with those of India. India was thus clearly the template against which he measured South Africa, including in the most mundane matters. Basically the view that Gandhi formed of the land in his early years was that of an imperial dependency where Indians, who had been thrown there by the workings of imperial policies, had, in spite of their unhappy circumstances, a duty to uphold the dignity of the motherland against the constant challenges thrown up by the white settlers and the imperial authorities. Although he tried to enrol the sympathies of some liberal-minded local whites, his basic political strategy was to appeal as much as possible to the imperial authorities against the white settlers. This led him to support the British in their war against the Boers in 1899-1901 by raising a unit of Indian stretcher-bearers who accompanied the troops to the front. He did it, in spite of his own avowed sympathies for the Boer cause. This sympathy was not because he harboured particularly warm feelings towards those settlers of Dutch origin who were even more fiercely racist than the British, but because he saw them, as many did then in the world at large, as victims of British oppression. His position on the war was however mostly of a tactical nature: he hoped that, in return for helping the British in their hour of need, Indians would receive more generous treatment. The realization that it would not be the case drove him to leave South Africa in 1901, and to try to restart his career in India. He was however recalled in 1902 by his compatriots, and struggled then in vain with the colonial bureaucracy to obtain relief for the hard-pressed Indians.

It has been noted by many, and has been a subject of heated public debate in South Africa, in the post-apartheid era, that Gandhi did not seek an alliance with the most oppressed group in South Africa, the Africans. I shall not enter into a detailed discussion of his attitude towards the latter (whom he called, according to contemporary local usage, Negroes or Kaffirs ${ }^{10}$ ). Let me just stress the fact that for Gandhi the Indians were in essence different from the Africans because they belonged to a high civilization, while the former were at an earlier stage of development, ${ }^{11}$ and that Indians had to resist all attempts by the white settlers to bring them down to the level of the Africans. The fact that Gandhi shared widespread European-derived prejudices about the low level of civilization reached by Africans should not surprise us, given the kind of intellectual influences he had been subject to in India. Ranking human groups on a scale of civilization was then a widespread intellectual fashion, and Indian literati tended to embrace it, as they could find some comfort in the fact that, in British eyes, they were not the lowest of the low. Besides, from a purely instrumental point of view, it would have been counterproductive, in the South Africa of the 1890s, for anyone aiming to defend the Indian cause, to stress any similarity of interests between Indians and Africans. It made more sense to present Indians as a separate group deserving of a more generous treatment. This may explain why Gandhi ignored (deliberately?) the fact that, in Natal, relations of intimacy sometimes developed between Indians and Africans. Because of a deficit of Indian women, some Indian men had taken up with African women, and there existed a small group of mixed race children. ${ }^{12}$ As far as Gandhi was concerned, it is clear that 'Africanization' was not a palatable option for the Indians of South Africa. As noted by two South African historians of Indian origin, 'Gandhi occasionally spoke out against racism and discrimination and even commented on the abject plight of African people, but he did not argue for equality for them. If he did not feel the need to spell out how Indians should relate to Africans, it was because he remained firmly focused on an imperial approach that put India at the centre of his thinking. ${ }^{13}$ 
6 In an open letter to Natal legislators written at the end of 1894 to enrol their support against a bill seeking to disenfranchise Indian voters (of whom there were only 250, mostly traders, out of a total of some 10,000 voters), Gandhi, in his defence of Indians' voting rights, put forward the argument that they belonged to the Aryan race, like Britons, and that 'India is not Africa, and is a civilized country in the truest sense of the term 'civilization". ${ }^{14}$ In Gandhi's view, their Aryan identity was one of the two basic resources the Indians could draw upon, the other one being the fact that they were British subjects.

7 While he perceived the Indian community of South Africa as an offshoot of the motherland, this did not prevent him from noticing some differences between the Indians of India and those of South Africa, for instance in the matter of language. In an aside he described the 'local Hindustani' as 'a grotesque mixture of Tamil, Gujarati and other Indian languages, clothed in extremely bad Hindustani grammar'. ${ }^{15}$ But his main emphasis was on sameness rather than on difference. Indians in South Africa, according to him, had an obligation never to forget that they were Indians, in spite of the distance separating them from the motherland, a distance that was not only physical, but also mental.

8 Actually one of Gandhi's aims was precisely to abolish that distance, in particular through a very idiosyncratic practice of journalism. In an interesting article on 'Gandhi's printing press', ${ }^{16}$ the press that Gandhi brought from India in 1898 for his newspaper Indian Opinion , the South African historian Isabel Hofmeyr has argued that Gandhi sought to establish an intimate relationship between himself as editor and his readers through a mode of reporting that was based on a constant circulation between the two locations of India and South Africa. Thus events involving the Indians of South Africa were reported via dispatches coming from India. The result was 'a mode of simultaneous reading as if the event were taking place in India and South Africa at the same time and as if the reader could inhabit both spaces' . ${ }^{17}$ 'Inhabiting both spaces' seems an apt description of Gandhi's South African project. There was of course a utopian dimension to it, given that the future Mahatma, as well as his readers, were after all but earthbound creatures not endowed with a gift of ubiquity. In spite of that, the phrase captures well Gandhi's aspiration not to let the umbilical cord linking Mother India with its children across the Ocean be cut. Here I am deliberately mixing metaphors, in order to try to grasp something fairly unique in terms of the politics of diasporas. That the nation, that 'imagined community', ${ }^{18}$ can be imagined with more clarity from the distance of exile is a banality. Suffice it to think of the Irish Fenians in America, or of Sun Yat Sen (1886-1925) creating his Chinese Nationalist Party (1912) in Hawaii. But Gandhi's South African story does not quite fit that pattern. For, unlike De Valera (1882-1975) or Sun Yat Sen, he did not arrive in South Africa with a preconceived and well formed notion of what India was politically. On the contrary, his view of India was shaped through a process of circulation between South Africa and India. In South Africa, he went through what could be described as an epiphany, as he was able to develop a sort of 'panoptic' vision of the very diverse groups of Indians there as forming one community defined by the kind of discrimination they were all subjected to, although in varying degrees. But that vision had to be constantly validated through it being taken up as a cause in India itself. Hence Gandhi's first 'propaganda tour' in India in 1896 to alert Indian public opinion to the condition of Indians in South Africa, ${ }^{19}$ that led to his being almost lynched by the white settlers on his return to Durban. What I want to stress is that, without a constant 
interaction with India, Gandhi could not have sustained this vision. But a reversal occurred from 1906 onwards with the invention of satyagraha, in the course of the struggle against the Transvaal Asiatic Amendments Act, known as the 'Black Act', an invention that Gandhi saw as divinely inspired, and the result of a kind of predestination. It followed Gandhi's own move, in 1905, from Durban to Johannesburg, where he started a successful law practice. At the beginning of 1906, while he was attending to some wounded Zulu prisoners with a small ambulance corps he had raised, following a rising of that African group and its violent suppression by the colonial authorities, he had the revelation that he should become brahmacharya (celibate) and devote his entire life to public action..$^{20}$ This resulted in a complete change in his trajectory, from successful lawyer to activist and jailbird, which produced in its turn a change in his view of South Africa. Because satyagraha had been born in South Africa, and was then practiced there in a succession of struggles between 1906 and 1914, the relationship of that land to India was not any more one-way. The land of South Africa had been sanctified by the sacrifices made by the Indians there in defence of their own dignity, and therefore of the dignity of the motherland. In spite of the blood spilled by the martyred satyagrahis on South African soil, there remained however a hierarchy of sacredness between South Africa and India. This was clearly expressed by Gandhi himself in one of the innumerable farewell addresses he gave at the time of his departure from South Africa in the summer of 1914. After having told his mostly Gujarati audience that he was 'extremely sad to part from (them)', he added: 'I am about to leave a bhoga-bhumi (land of enjoyment) ${ }^{21}$ for a karmabhumi (land of duty). For me, there can be no deliverance from this earthly life except in India. Anyone who seeks such deliverance must go to the sacred soil of India. For me, as for everyone else, the land of India is 'the refuge of the afflicted'. I am therefore longing to return to the motherland'..$^{22}$ Why only the matrabhumi (motherland) could be a karmabhumi was not explicated, but a hint was that it had 'been sanctified by the austerities of the ages'. ${ }^{23}$ There remained in Gandhi's mind, during his entire South African stay, the notion that South Africa by itself was an empty land, in the sense of a land empty of meaning. Indians, by their struggles, could endow it with meaning, but this they could do only if they kept a close link to India. Thus, in an address to the 'colonial-born Indians', he exhorted them to 'preserve their national characteristic, to learn their mother-tongue ( sic) and study the history and traditions of their Motherland'. ${ }^{24} \mathrm{He}$ also expressed the hope to 'see them there one day'. In the last years of his South African stay, it is clear that Gandhi saw South Africa as a kind of laboratory for experiments in struggle that could at a later stage be replicated in India. Congress moderate leader Gokhale's visit to South Africa in 1912, which Gandhi carefully organized at each and every stage, was a crucial moment in his new project, as he could thence present himself to public opinion in India as a favourite disciple and prospective heir to the great man, whose fragile state of health was known to all. He just needed one symbolic success in South Africa to be able to come back to India with his head held high, and he obtained it in 1914 with the Indian Relief Act legalizing Indian marriages. He then left South Africa for ever, although he left there a son, close friends, a newspaper. They would have to manage without him.

What does this story tell us about India as a political/spatial category? Gandhi's ability to somewhat straddle the Indian Ocean to inhabit two spaces at the same time remains a rather unique feat. It ran contrary to a trend towards seeing India as part of Asia that developed in Indian nationalist circles, mostly in Bengal, in the wake of the RussoJapanese war of 1904 05. Gandhi was never tempted to 'look east' towards Tokyo, as Rabindranath Tagore and other literati were at the time. ${ }^{25}$ For him, India did not belong 
to Asia, it was a world of its own, susceptible of encompassing any place on earth where Indians toiled and suffered. In that sense, we can speculate that he would not have taken to the idea of 'South Asia' that anchors India firmly in the Asian continent. Hofmeyr suggests that he saw India as part of a cosmopolitan 'Indian ocean world', of which South Africa was also part. ${ }^{26}$ This appears dubious. To Gandhi, I would argue, the Indian Ocean was simply a waterway that one had to cross, rather than a space endowed with qualities of its own. In spite of having travelled a lot by ship, he does not strike me as very seaoriented. Although I would agree that Gandhi was in many ways a cosmopolitan figure, I do not see his cosmopolitanism as specifically bound to the Indian Ocean. Prior to 1919 a more crucial spatial dimension for him was that of the British Empire, that straddled the whole world. Once he distanced himself from the Empire, he was left without any other space than India, a cosmopolitan without a cosmos. Hence his horror at the idea that that space itself could be partitioned as it was in 1947.

This opens up the whole delicate chapter of his relationship with Muslims. In South Africa, he forged close links with Muslim merchants, and some of them, like Seth Kachhalia, were amongst his closest associates, even if they do not appear to have become intimate friends in the same way as Europeans like Hermann Kallenbach or Henry Polak. It is also amongst Muslims that he found some of his most determined opponents, who rejected his non-violent tactics. But, in spite of his political proximity to some Muslims, he does not appear to have acquired a deep knowledge about Islam. Thus, in one text, he claimed that Muslims prayed 'four times a day'. ${ }^{27}$ His knowledge of Islamic law also appears to have been limited, and one European judge, in a court case concerning the succession of a Muslim merchant, accused him of being totally ignorant of Islamic law. ${ }^{28}$ In his writings, the references to the Holy Christian scriptures far outnumber the Koranic references, a reminder that Gandhi as an intellectual was a product of as well as a producer of a particular synthesis of Christian and neo-Hindu elements. His notion of India as a sacred land is obviously a very Hindu idea, but, contrary to Peter Van der Veer, ${ }^{29}$ I do not see Gandhi as a 'moderate' Hindu nationalist, by contrast with extremists like Savarkar (1883-1966). His nationalism and his Hinduism remained in separate spheres. He never identified the 'Indian nation' with a 'Hindu nation', and his conception of it was always inclusive of Indians of all faiths, whether Muslim, Sikh, Christian, Zoroastrian or Jewish. $^{30}$ The problem was rather one of communication: Gandhi increasingly made use, in his public utterances, of an idiom that was strongly Hindu-connoted, and this tended to alienate non-Hindus, particularly educated Muslims. This shift in language started in the last years of Gandhi's stay in South Africa, and coincided with a change in sartorial habits, with the adoption of the lungi (loincloth) and kurta (loose shirt) instead of the three-piece suit of the lawyer. ${ }^{31}$ It signalled a strong desire on the part of Gandhi to appear fully Indian and to remove all traces of his former 'Westernized' self, as a prelude to his return to the motherland. Yet, as we know, the re-adaptation of Gandhi to the Indian setting was a process that took a few years, a clear sign that the impact of the South African stay had been even more profound than Gandhi himself realized. The India to which Gandhi reacclimatized himself between 1915 and 1919 was far from living up to the idealized image he had conjured of it in his self-imposed exile. The realization of the true state of the country drove Gandhi to a gradual break with moderate politics. He tried however to maintain something of his former cosmopolitanism, but his turn to a more nationalistic position made it problematic. As a way of resolving this contradiction, his cosmopolitanism took a messianic form and he tended increasingly to see India as offering a way of redemption to the world at large. That is why, to conclude by returning 
to 'the idea of South Asia', I think it doubtful that Gandhi would have reconciled himself to the idea of India being only one part of a wider space called 'South Asia', but of course this has to remain in the realm of speculation.

\section{BIBLIOGRAPHY}

Anderson, Benedict (1991) Imagined Communities: Reflections on the Origin and Spread of Nationalism, London: Verso.

Bhana, Surendra; Vahed, Goolam (2005) The Making of a Political Reformer: Gandhi in South Africa, 1893-1914, Delhi: Manohar.

Collected Works of Mahatma Gandhi (online edition), vols. 1 \& 14.

Gandhi, Mohandas Karamchand (1928) Satyagraha in South Africa, Ahmedabad: Navajivan Publishing House.

Gandhi, Mohandas Karamchand (1972) An Autobiography: The Story of My Experiments with Truth, London: Jonathan Cape.

Hay, Stephen N. (1970) Asian Ideas of East and West: Tagore and his Critics in Japan, China and India, Cambridge (Mass.): Harvard University Press.

Hofmeyr, Isabel (2011) ‘Gandhi’s Printing Press: Indian Ocean Print Culture and Cosmopolitanism', in Isabel Hofmeyr \& Michelle William (eds.), South Africa and India: Shaping the Global South, Johannesburg: Wits University Press, pp. 22-38.

Markovits, Claude (2003) The Un-Gandhian Gandhi: The Life and Afterlife of the Mahatma, Delhi: Permanent Black.

Markovits, Claude ( 2008) 'Religious Boundaries and the Nation in Gandhi's Thought and Action', in Monica Juneja \& Margrit Pernau (eds.), Religion und Grenzen in Indien und Deutschland: Auf dem Weg zu einer Transnationalen Historiographie, Göttingen: V\&R Unipress, pp. 207-21.

Marks, Shula (2011) 'Class, Culture and Consciousness in South Africa 1880-1899', in Robert Ross, Ann Kelk Mager \& Bill Nasson (eds.), The Cambridge History of South Africa, vol. 2, 1885-1994,

Cambridge: Cambridge University Press, pp. 102-156.

Swan, Maureen (1985) Gandhi, The South African Experience, Johannesburg: Ravan Press.

Tarlo, Emma (1996) Clothing Matters: Dress and Identity in India, London: Hurst \& Co.

Tinker, Hugh (1994) A New System of Slavery: The Export of Indian Labour Overseas 1830-1920, London: Hansib Publishing, [1974].

Van der Veer, Peter (1994) Religious Nationalism: Hindus and Muslims in India, Berkeley, Los Angeles \& London: University of California Press. 


\section{NOTES}

1. For an emphatic statement of the importance of the South African years, see Markovits (2003: 78-85).

2. Swan (1985), Bhana \& Vahed (2005).

3. Gandhi (1972: 85-287).

4. Gandhi (1928).

5. Tinker (1994).

6. Gandhi (1972: 93-94).

7. A Muslim merchant of Johannesburg told Gandhi (1972: 97): 'Only we can live in a land like this, because, for making money, we do not mind pocketing insults.'

8. He wrote in the Autobiography (1972: 181): '...ever since my settlement in Natal, I had been endeavouring to clear the community of a charge that had been levelled against it, not without a certain amount of truth. The charge had often been made that the Indian was slovenly in his habits and did not keep his house and surroundings clean.'

9. Having stated that 'The scenery of Durban is considered very beautiful, but that of Cape Town surpasses it', he goes on to quote from a poem by 'a gifted lady who dotes on South Africa', Gandhi (1928: 6).

10. A derogatory term for Africans used mostly by the Boers.

11. Although he wrote: 'It is only vanity that makes us look upon the Negroes as savages. They are not the barbarians we imagine them to be' (1928: 10), that passage was written in 1924, ten years after his return from South Africa, and looks very much like an atonement for past sins.

12. Shula Marks (2011: 140) notes: 'In rural Natal...Indians often became fluent Zulu speakers and very occasionally sex and marriage took place across a cultural divide'.

13. Bhana \& Vahed (2005: 144).

14. Collected Works of Mahatma Gandhi (CWMG), online edition, vol. I: 186-200.

15. CWMG, online edition, vol. I: 186-200.

16. Hofmeyr (2011).

17. Hofmeyr (2011: 34).

18. Anderson (1991).

19. 'The Grievances of the British Indians in South Africa as exposed to the Indian public', Rajkot, 14 August 1896, no. 101, CWMG, vol. I: 359-93.

20. Gandhi (1972: 263-267).

21. This translation, offered by the editor of the CWMG, is not satisfactory, as pointed out by Catherine Clémentin-Ojha. 'Bhoga' refers to any form of activity in the world.

22. 'Speech at Gujarat Sabha function', 9 July 1914, CWMG, 14(190), pp. 210-1.

23. In a speech at another farewell meeting on 8 July 1914. CWMG, 14(184), pp. 200-2.

24. Indian Opinion. 1914. 9 September.

25. Hay (1970).

26. Hofmeyr (2011).

27. CWMG, vol. I: 191.This is obviously not a misprint; otherwise, it would have been corrected by the editors.

28. Sir Walther Wragg, as quoted in Natal Witness. CWMG, vol. I, note 1: 209.

29. Van der Veer (1994: 95): 'We cannot fail to notice that Gandhi's pluralist nationalism retains a Hindu character'.

30. Markovits (2008).

31. Tarlo (1996). 


\section{ABSTRACTS}

The focus of the article is the way in which Gandhi in South Africa between 1893 and 1914 constructed a notion of India through a process of partly imaginary circulation between South Africa and India. While he embarked upon a career, firstly as spokesman, and then as leader of the very diverse Indian population of South Africa, he tried to remain in touch with political developments in India. His attempt at 'inhabiting two spaces at the same time', while necessarily utopian in character, nevertheless offers a fascinating case study in 'long distance nationalism', and the way it was intertwined with forms of cosmopolitanism. There is no indication however of an inclination on the part of Gandhi to think in terms of a wider space that would extend to contemporary South Asia.

\section{INDEX}

Keywords: Gandhi, South Asia, India, South Africa, diaspora, cosmopolitanism

\section{AUTHOR}

\section{CLAUDE MARKOVITS}

Emeritus Researcher, CNRS/CEIAS, Paris 